\title{
The Sensitive Period for Male-to-Female Sex Reversal Begins at the Embryonic Stage in the Nile Tilapia and is Associated With the Sexual Genotype
}

\author{
VINCENT GENNOTTE, ${ }^{1 *}$ CHARLES MÉLARD, ${ }^{1}$ HELENAD'COTTA, ${ }^{2}$ JEAN-FRANÇOISBAROILLER,${ }^{2}$ AND CAROLE ROUGEOT ${ }^{1}$ \\ ${ }^{1}$ Aquaculture Research and Education Center (CEFRA), AFFISH-RC, University of Liège, Tihange, Belgium \\ ${ }^{2}$ UMR Intrepid, Department Persyst, CIRAD, Campus International de Baillarguet, Montpellier, France
}

\section{SUMMARY}

In this study, we sought to determine the mechanism of early sex reversal in a teleost by applying $4 \mathrm{hr}$ feminization treatments to $X Y\left(17 \alpha\right.$-ethynylestradiol $\left.2000 \mu \mathrm{gL}^{-1}\right)$ and $Y Y\left(6500 \mu \mathrm{g} \mathrm{L}^{-1}\right)$ Nile tilapia embryos on the first day post-fertilization (dpf). We then searched for changes in the expression profiles of some sex-differentiating genes in the brain (cyp19a1b, fox/2, and $a m h$ ) and in sex steroids (testosterone, $17 \beta$-estradiol, and 11-ketotestosterone) concentrations during embryogenesis and gonad differentiation. No sex reversal was observed in $Y Y$ individuals, whereas sexreversal rates in $X Y$ progeny ranged from $0-60 \%$. These results, together with the clearance profile of $17 \alpha$-ethynylestradiol, confirmed the existence of an early sensitive period for sex determination that encompasses embryonic and larval development and is active prior to any sign of gonad differentiation. Estrogen treatment induced elevated expression of cyp 19a1b and higher testosterone and 17 $\beta$-estradiol concentrations at $4 \mathrm{dpf}$ in both $X Y$ and $Y Y$ individuals. fox $/ 2$ and amh were repressed at $4 \mathrm{dpf}$ and their expression levels were not different between treated and control groups at $14 \mathrm{dpf}$, suggesting that fox/2 did not control cyp19a1b in the brains of tilapia embryos. Increased cyp19a1b expression in treated embryos could reflect early brain sexualization, although this difference alone cannot account for the observed sex reversal as the treatment was ineffective in $Y Y$ individuals. The differential sensitivity of $X Y$ and $Y Y$ genotypes to embryonic induced-feminization suggests that a sex determinant on the sex chromosomes, such as a $Y$ repressor or an $X$ activator, may influence sex reversal during the first steps of tilapia embryogenesis.

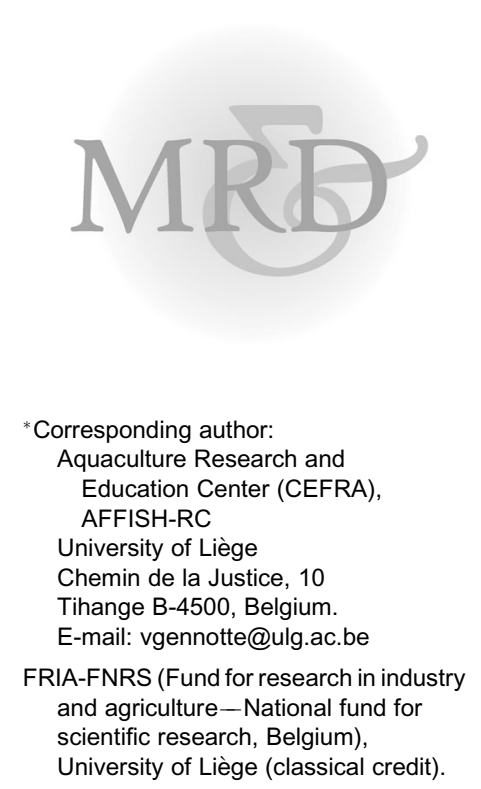

Mol. Reprod. Dev. 81: 1146-1158, 2014. (c) 2014 Wiley Periodicals, Inc.

Published online 5 December 2014 in Wiley Online Library (wileyonlinelibrary.com).

Received 30 June 2014; Accepted 21 October 2014 DOI $10.1002 / \mathrm{mrd} .22436$

\section{INTRODUCTION}

While the process of sex determination is relatively conserved and relies on a single pathway in the majority of mammals, fish utilize many different sex-determining systems that exist along a continuum ranging from pure genetic determination (chromosomal XY, ZW, or polygenic) to environmental determination (Devlin and Nagahama, 2002). In fish with genetic sex determination, a master sex- determining gene similar to the mammalian SRY (Sinclair et al., 1990) was characterized in a few species: dmy in the

\footnotetext{
Abbreviations: $11 \mathrm{KT}, 11-\mathrm{ket}$ testosetrone; dpf, days post-fertilization; E2, $17 \beta$-estradiol; EE2, $17 \alpha$-ethynylestradiol; hpf, hours post-fertilization; P\#, population number; T, Testosterone.; amh, anti-Müllerian hormone; cyp19a1, cytochrome P450 aromatase; fox/2, forkhead box 12 transcription factor
} 
medaka Oryzias latipes (Matsuda et al., 2002), gsdf in Oryzias luzonensis (Myosho et al., 2012), amhy in the Patagonian pejerrey Odontesthes hatchery (Hattori et al., 2012), amhr2in the tigerpufferfish Takifugu rubripes (Kamiya et al., 2012), and $s d Y$ in the rainbow trout Oncorhynchus mykiss (Yano et al., 2012). Of the most-important genes acting downstream of Sry analogs during sexual differentiation, amh (anti-Müllerian hormone) is associated with testis differentiation while fox/2 (forkhead boxl2transcriptionfactor) and cyp19a1 (cytochrome P450 aromatase) are linked to ovarian development (Siegfried, 2010).

The role of amh during male differentiation in fish is still unclear as teleosts do not have Müllerian ducts. The finding of amhy, a duplicated gene on the $Y$ chromosome of pejerrey, and its receptor amhr2 as sex determinants reflects the importance of amh signaling in certain fish (Hattori et al., 2012; Kamiya et al., 2012). In tilapia, higher expression of amh is observed in the differentiating testis starting around 20 days post-fertilization (dpf) and remains at a higher level (ljiri et al., 2008; Poonlaphdecha et al., 2011). Its dimorphic expression appears early in the brain of males, at the onset of gonad differentiation (10 dpf), suggesting an additional role in brain sexualization (Poonlaphdecha et al., 2011).

Fox/2, on the other hand, is expressed in a femalespecific manner in the developing gonads of mammals, birds, reptiles (Loffler et al., 2003), and fish (Guiguen et al., 2010). In medaka, fox/2 is up-regulated at the first stages of ovarian differentiation (Nakamoto et al., 2006). In tilapia, its sexually dimorphic expression was reported as early as 9 $\mathrm{dpf}$, before any sign of histological differentiation (Ijiri et al., 2008). An in vitro study in tilapia identified fox/2 as an important regulator of cyp19a1 transcription (Wang et al., 2007); indeed these two genes are co-expressed in the differentiating ovaries of rainbow trout (Vizziano-Cantonnet et al., 2011) and tilapia (Wang et al., 2007).

Aromatase, encoded by cyp19a1a for the gonad form and cyp19a1b for the brain form (Tchoudakova and Callard 1998; Kwon et al., 2001), is responsible for estrogen synthesis, and therefore plays a key role in sexual steroidogenesis and gonad differentiation in fish (see reviews by Diotel et al., 2010 and Guiguen et al., 2010). For example, administration of estrogens to genetic males during the sex differentiation period induced feminization of the gonads in different species (Piferrer, 2001; Devlin and Nagahama, 2002) whereas treatment of fry with aromatase inhibitor leads to masculinization in genetic females (Piferrer et al., 1994; Afonso et al., 2001; Uchida et al., 2004). In rainbow trout, cyp19a1a is up-regulated in the differentiating ovary (von Schalburg et al., 2010) while in tilapia, expression of cyp19a1a is up-regulated in female gonads from $9 \mathrm{dpf}$ onwards (D'Cotta et al., 2001; ljiri et al., 2008; Poonlaphdecha et al., 2013) and cyp19a1b is expressed in the brain very early during ontogenesis, with no difference in expression profiles between sexes (Kwon et al., 2001). Although the regulatory pathways of cypa19a1a and cyp19a1b have their specificities, several authors suggested a possible role for brain aromatase during brain and the gonad sexualization in gonochoristic teleosts (Tsai et al., 2003; Blázquez and Somoza, 2010; Le Page et al., 2010).
Nile tilapia has an $X X / X Y$ sex determination system that can be overridden by exogenous steroids and high temperature (masculinizing effect above $32^{\circ} \mathrm{C}$ ) (Jalabert et al., 1974; Baroiller et al., 1995, 1999). The sensitive period extends from $10 \mathrm{dpf}$ (yolk-sac resorption) to 25-30 dpf (formation of an ovarian cavity or an intratesticular efferent duct) (Kobayashi et al., 2008). Temperature-induced masculinization up-regulates gonad expression of amh while repressing both fox $/ 2$ and cyp19a1a expression as well as brain aromatase activity (D'Cotta et al., 2001; Poonlaphdecha et al., 2013). In contrast, estrogen-feminizing treatments up-regulate the expression of both cyp19a1 genes (Kobayashi et al., 2003). Several authors suggest that tilapia also possesses a second sensitive window for sex determination, starting earlier in the embryonic phase. Rosenstein and Hulata (1992) attempted to feminize Mozambique tilapia (O. mossambicus) using short estrogen (17ßestradiol, progesterone, and flutamide) immersions of freshly fertilized eggs, but found a similar number of females in treated and control groups. Rougeot et al. $(2008 a, b)$ showed that thermal $\left(>34^{\circ} \mathrm{C}\right)$ and hormonal $(17 \alpha$-methyltestosterone, $17 \alpha$-ethynylestradiol) treatments of embryos from $12 \mathrm{hr}$ post-fertilization (hpf) to hatching induced, respectively, up to $27 \%$ and $68 \%$ sex reversal in O. niloticus. They suggested that early sex reversal treatments could act on the development of primordial germ cells, apparent as early as $46 \mathrm{hpf}$, and/ or somatic cells of the future gonad, or could influence brain sexualization since the brain starts to differentiate at $31 \mathrm{hpf}$ (Morrison et al., 2001). A separate model that must be considered when interpreting how these early hormonal treatments affect the sex-reversal mechanism is the possible accumulation of hormones in the embryo and the vitellus, which could lead to a delayed effect on embryogenesis such that the hormones act directly on the developing gonad (Piferrer and Donaldson, 1994). Characterization of the uptake and clearance kinetics of $17 \alpha$-ethynylestradiol (EE2) administered to $\mathrm{XY}$ embryos following Rougeot's procedure showed that the whole-body concentration of EE2 at the onset of gonad differentiation (10 dpf) was still very high (unpublished data). Such delayed and prolonged hormonal supply makes the identification of the period of hormone action and target structure more difficult because of its ambiguity.

The present study aimed to substantiate the existence of a precocious sensitive period for sex reversal in Nile tilapia, before the development of a gonadal primordium tissue, and to explore the mechanism(s) of sex reversal during this period. We used short EE2 immersion treatments applied at early embryonic stages to switch the phenotypic sex of XY Nile tilapia. EE2 uptake and clearance were followed to confirm early action of the exogenous hormone. Similar treatments were applied to YY embryos to test the influence of sexual genotype on sex-reversal sensitivity and on the sex determination process. Sex-reversal mechanisms and the hypothetical upstream role of the brain in the sex determination process were investigated through the measurements of the natural sexual steroids (testosterone, $17 \beta$-estradiol, and 11-ketotestosterone) and the expression of three main sex-differentiating genes (cyp19a1b, $a m h$, and fox/2) in the heads of treated embryos and juveniles. 


\section{RESULTS}

\section{Growth, Survival, and Sex-Ratios}

Immersion treatments did not significantly affect the growth of $X Y$ progeny during the whole experimental period (Fig. 1A). At $35 \mathrm{dpf}$, mean body weight of the three groups were: $651 \pm 14 \mathrm{mg}$ for the group immersed at $1 \mathrm{dpf}$ for $4 \mathrm{hr}$ in a dose of $2000 \mu \mathrm{g} \mathrm{EE} 2 \mathrm{~L}^{-1}$ (XY2000), $643 \pm 12 \mathrm{mg}$ for the controls (XYC) immersed in ethanol 1:1000, and $649 \pm 15 \mathrm{mg}$ in the group immersed at $10 \mathrm{dpf}$ for $4 \mathrm{hr}$ in a dose of $20 \mu \mathrm{g} \mathrm{EE} 2 \mathrm{~L}^{-1}$ (XY20).

Growth was very similar between the $Y Y$ progeny as well (Fig. 1B), and immersion treatment did not affect the mean body weight of the fish immersed at $1 \mathrm{dpf}$ for $4 \mathrm{hr}$ in a $6500 \mu \mathrm{g}$ EE2 $\mathrm{L}^{-1}$ solution (YY6500) or in the controls (YYC) immersed at $1 \mathrm{dpf}$ for $4 \mathrm{hr}$ in ethanol 1:1000. In the group fed from 10-40 dpf with $500 \mathrm{mg} \mathrm{EE} 2 \mathrm{~kg}^{-1}$ food (YYD), which served as a positive control for sex reversal, growth slowed down after 19 days of treatment ( $28 \mathrm{dpf}$ ), resulting in a significantly different mean body weight from both YYC and YY6500 at 35 and $42 \mathrm{dpf}$. At the end of the experiment (42 dpf), the mean body weights were respectively $838 \pm 73$, $864 \pm 80$, and $433 \pm 64 \mathrm{mg}$ in YYC, YY6500, and YYD progeny.

Survival rates in the $X Y$ progenies ranged from $11-29 \%$ in XYC, from $16-34 \%$ in XY2000, and from $24-50 \%$ in $X Y 20$ groups (Table 1). Mean values were not significantly different between XYC and XY2000, but the mean survival rate was significantly higher in the $X Y 20$ group than in the controls. In $Y Y$ progeny, survival rates ranged from $38-58 \%$ in $Y Y C$, from $25-45 \%$ in $Y Y 6500$, and from $53-71 \%$ in YYD groups. The mean survival rate was significantly higher in YYD compared to YYC and YY6500 progeny.

Sex-ratio analysis revealed the expected absence of females in the control groups (XYC and YYC) (Table 1). In $X Y$ individuals, the efficiency of EE2 immersion treatments differed between progeny. The proportion of females in XY2000 ranged from $0.9-60.6 \%$. Except for population 4
(P4) progeny, immersion treatment with a dose of $2000 \mu \mathrm{g}$ $\mathrm{L}^{-1}$ EE2 for $4 \mathrm{hr}$ applied to 1 day-old embryos (XY2000) significantly skewed the sex ratios toward females, with the highest values for P2 (60.6\%) and P5 (23.0\%). Immersion treatment of 10-days-old larvae at $20 \mu \mathrm{g} \mathrm{L}^{-1} \mathrm{EE} 2$ resulted in significant sex reversal only in these two progeny populations, at $8.6 \%$ and $4.0 \%$ of females for $\mathrm{P} 2$ and $\mathrm{P} 5$, respectively, suggesting their increased sensitivity to steroid feminization. In YY progeny, however, EE2 immersion treatment at $1 \mathrm{dpf}$ did not lead to any significant sex reversal, although these populations were clearly susceptible as dietary EE2 treatment (from 10-40 dpf) achieved sex reversal efficiencies of $83.7-100 \%$.

\section{EE2 Uptake and Clearance}

The EE2 used for the feminization treatment of $X Y$ embryos (XY2000 group, $2000 \mu \mathrm{gL}^{-1}$ at $1 \mathrm{dpf}$ ) passed through the chorion and rapidly accumulated in the eggs, resulting in a mean concentration of $18929 \pm 3565 \mathrm{ng} \mathrm{g}^{-1}$ shortly after the immersion (Fig. 2A). This surge represented a 10-fold bioconcentration of the hormone compared to the initial exposure dosage. Clearance kinetics were rapid, as the concentration dropped to $4798 \pm 465 \mathrm{ng}$ $\mathrm{g}^{-1}$ by $4 \mathrm{dpf}$ and returned to a value $\left(1.41 \pm 1.89 \mathrm{ng} \mathrm{g}^{-1}\right)$ statistically similar to the control at $21 \mathrm{dpf}$ (Fig. 2A and B).

The $20 \mu \mathrm{g} \mathrm{L}^{-1} \mathrm{EE} 2$ dose used for the $4 \mathrm{hr}$ treatment at 10 dpf (XY20) was chosen in order to reach the same tissue concentration as the $X Y 2000$ group, allowing us to test if the XY2000 treatment was active before $10 \mathrm{dpf}$. EE2 tissue concentration of XY20 was 3.5-fold higher than in XY2000 $\left(3975 \pm 995\right.$ and $1146 \pm 153 \mathrm{ng} \mathrm{g}^{-1}$ respectively) at $10 \mathrm{dpf}$ following treatment (Fig. 2B). One day after the treatment, however, the EE2 level of XY20 dropped to $397 \pm 39 \mathrm{ng} \mathrm{g}^{-1}$ and continued to decrease faster than in XY2000 individuals. At $14 \mathrm{dpf}$, the values of EE2 concentration in XY2000 $\left(28 \pm 12 \mathrm{ng} \mathrm{g}^{-1}\right)$ and $\mathrm{XY} 20\left(10 \pm 5 \mathrm{ng} \mathrm{g}^{-1}\right)$ were not significantly different, although they remained significantly higher
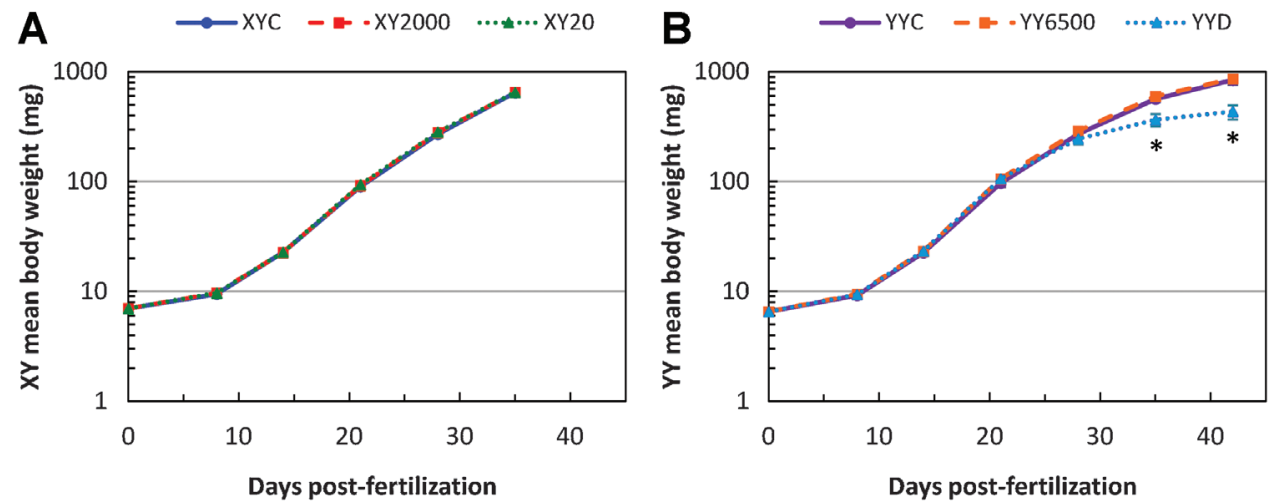

Figure 1. Mean growth curves of tilapia progeny during the experimental period in $(A) X Y(n=5)$ until $35 \mathrm{dpf}$ and $(B) Y Y(n=4)$ until $42 \mathrm{dpf}$. $X Y C$, $X Y$ control group; $X Y 2000, X Y$ batch that underwent an EE2 immersion treatment $\left(2000 \mu \mathrm{g} \mathrm{L}^{-1}\right)$ for $4 \mathrm{hr}$ at $1 \mathrm{dpf}$; $X Y 20, X Y$ batch immersed in EE2 at $20 \mu \mathrm{g} \mathrm{L}^{-1}$ for $4 \mathrm{hr}$ at $10 \mathrm{dpf}$; YYC, YY control group. YY6500, YY batch immersed in EE2 at $6500 \mu \mathrm{g} \mathrm{L}^{-1}$ for $4 \mathrm{hr}$ at $1 \mathrm{dpf}$; YYD, YY submitted to an EE2 dietary treatment of $500 \mathrm{mg} \mathrm{kg}^{-1}$ food from $10-40 \mathrm{dpf}$. ${ }^{*} P<0.05$. 
Embryonic Sex Reversal in Nile Tilapia

TABLE 1. Survival Rates in 5 XY (35 dpf; P1 to P5) and 4 YY (42 dpf; P6 to P9) Progeny, and Sex-Ratios (\% Females) at 90 dpf for Tilapias Submitted to EE2 Feminization Treatments

\begin{tabular}{|c|c|c|c|c|c|c|c|c|}
\hline & & $\mathrm{XYC}$ & XY2000 & XY20 & & YYC & YY6500 & YYD \\
\hline Survival (\%) & & $24.5 \pm 3.5^{a}$ & $27.7 \pm 3.2^{\mathrm{ab}}$ & $40.6 \pm 4.6^{b}$ & & $48.7 \pm 4.4^{a}$ & $37.9 \pm 4.7^{a}$ & $66.5 \pm 4.5^{\mathrm{b}}$ \\
\hline$\%$ females ( $n$ sexed) & $\begin{array}{l}\text { P1 } \\
\text { P2 } \\
\text { P3 } \\
\text { P4 } \\
\text { P5 } \\
\text { Mean }\end{array}$ & $\begin{array}{l}0.0^{\mathrm{a}}(53) \\
0.0^{\mathrm{a}}(125) \\
0.0^{\mathrm{a}}(110) \\
0.0^{\mathrm{a}}(106) \\
0.0^{\mathrm{a}}(100) \\
0.0 \pm 0.0^{\mathrm{a}}\end{array}$ & $\begin{array}{r}11.8^{\mathrm{b}}(68) \\
60.6^{\mathrm{c}}(109) \\
6.3^{\mathrm{b}}(111) \\
0.9^{\mathrm{a}}(106) \\
23.0^{\mathrm{c}}(100) \\
20.5 \pm 10.7^{\mathrm{c}}\end{array}$ & $\begin{array}{l}0.0^{\mathrm{a}}(66) \\
8.6^{\mathrm{b}}(93) \\
0.0^{\mathrm{a}}(101) \\
0.0^{\mathrm{a}}(104) \\
4.0^{\mathrm{b}}(101) \\
2.5 \pm 1.7^{\mathrm{b}}\end{array}$ & $\begin{array}{l}\text { P6 } \\
\text { P7 } \\
\text { P8 } \\
\text { P9 } \\
\text { Mean }\end{array}$ & $\begin{array}{l}0.0^{\mathrm{a}}(103) \\
0.0^{\mathrm{a}}(100) \\
0.0^{\mathrm{a}}(100) \\
0.0^{\mathrm{a}}(103) \\
0.0 \pm 0.0^{\mathrm{a}}\end{array}$ & $\begin{array}{l}0.9^{\mathrm{a}}(106) \\
0.8^{\mathrm{a}}(124) \\
0.0^{\mathrm{a}}(118) \\
0.0^{\mathrm{a}}(58) \\
0.4 \pm 0.3^{\mathrm{a}}\end{array}$ & $\begin{array}{r}99.1^{\mathrm{b}}(113) \\
100.0^{\mathrm{b}}(100) \\
99.0^{\mathrm{b}}(100) \\
83.7^{\mathrm{b}}(92) \\
95.5 \pm 3.9^{\mathrm{b}}\end{array}$ \\
\hline
\end{tabular}

$X Y C, X Y$ control group; $X Y 2000, X Y$ submitted to an EE2 immersion treatment $\left(2000 \mu \mathrm{g} \mathrm{L}^{-1}\right)$ for $4 \mathrm{hr}$ at $1 \mathrm{dpf} ; \mathrm{XY} 20, \mathrm{XY}$ immersed in EE2 at $20 \mu \mathrm{g} \mathrm{L}{ }^{-1}$ for $4 \mathrm{hr}$ at $10 \mathrm{dpf}$; YYC, YY control group; YY6500, YY immersed in EE2 at $6500 \mu \mathrm{g} \mathrm{L}^{-1}$ for $4 \mathrm{hr}$ at $1 \mathrm{dpf}$; YYD, YY submitted to an EE2 dietary treatment of $500 \mathrm{mg} \mathrm{kg}^{-1}$ food from $10-40$ dpf. Different superscript letters $(a, b$, or $\mathrm{c})$ indicate significant differences $(P<0.05)$

than the controls. As in XY2000, the hormone level in XY20 returned to a basal level close to $0 \mathrm{ng} \mathrm{g}^{-1}$ and was statistically similar to the controls at $21 \mathrm{dpf}\left(0.55 \pm 0.67 \mathrm{ng} \mathrm{g}^{-1}\right)$.

In YY feminization experiments at a high concentration of $6500 \mu \mathrm{g} \mathrm{L}^{-1}$ (YY6500), EE2 uptake and clearance followed the same profile as in XY2000, with a 10-fold bioconcentration of the hormone in the tissue immediately after immersion (Fig. 2C) and a maximum mean concentration of $62755 \pm 3691 \mathrm{ng} \mathrm{g}^{-1}$. EE2 level decreased thereafter to $6703 \pm 1789 \mathrm{ng} \mathrm{g}^{-1}$ at $10 \mathrm{dpf}$. At $14 \mathrm{dpf}$, the concentration in YY6500 $\left(28 \pm 7 \mathrm{ng} \mathrm{g}^{-1}\right)$ was equal to that measured in $\mathrm{XY} 2000$, and returned to a level $\left(0.26 \pm 0.03 \mathrm{ng} \mathrm{g}^{-1}\right)$ statistically similar to the control at $21 \mathrm{dpf}$ (Fig. 2D). In the dietary EE2 groups (YYD) given a dose of $500 \mathrm{mg} \mathrm{EE}^{2} \mathrm{~kg}^{-1}$ in their food from 10-40 dpf, the EE2 tissue concentration slowly increased to $166 \pm 44 \mathrm{ng} \mathrm{g}^{-1}$ at $14 \mathrm{dpf}, 442 \pm 40 \mathrm{ng} \mathrm{g}^{-1}$ at 21 $\mathrm{dpf}$, and reached a maximum of $1792 \pm 295 \mathrm{ng} \mathrm{g}^{-1}$ at the end of the treatment period ( $40 \mathrm{dpf}$ ) (Fig. 2D). As soon as the hormonal treatment ended, the concentration decreased rapidly to $139 \pm 21 \mathrm{ng} \mathrm{g}^{-1}$ at $42 \mathrm{dpf}$.

\section{Testosterone, $17 \beta$-Estradiol, and 11-Ketotestosterone Profiles}

Eggs at $0 \mathrm{dpf}$ contained high levels of testosterone $(T)$ and $17 \beta$-estradiol (E2) in both XY (Fig. 3A and C) and YY (Fig. 3B and D) progeny. The maximal values were measured at $1 \mathrm{dpf}$ (except for T in YY): $58 \pm 5 \mathrm{ng} \mathrm{T}^{-1}$ and $45 \pm 11 \mathrm{ngE}^{-1} \mathrm{~g}^{-1}$ in $\mathrm{XYC} ; 37 \pm 9 \mathrm{ng} \mathrm{T}^{-1}$ and $67 \pm 6 \mathrm{ng} \mathrm{E} 2 \mathrm{~g}^{-1}$ in YYC. After 1 $\mathrm{dpf}$, concentrations of T and E2 decreased until 10-14 dpf,
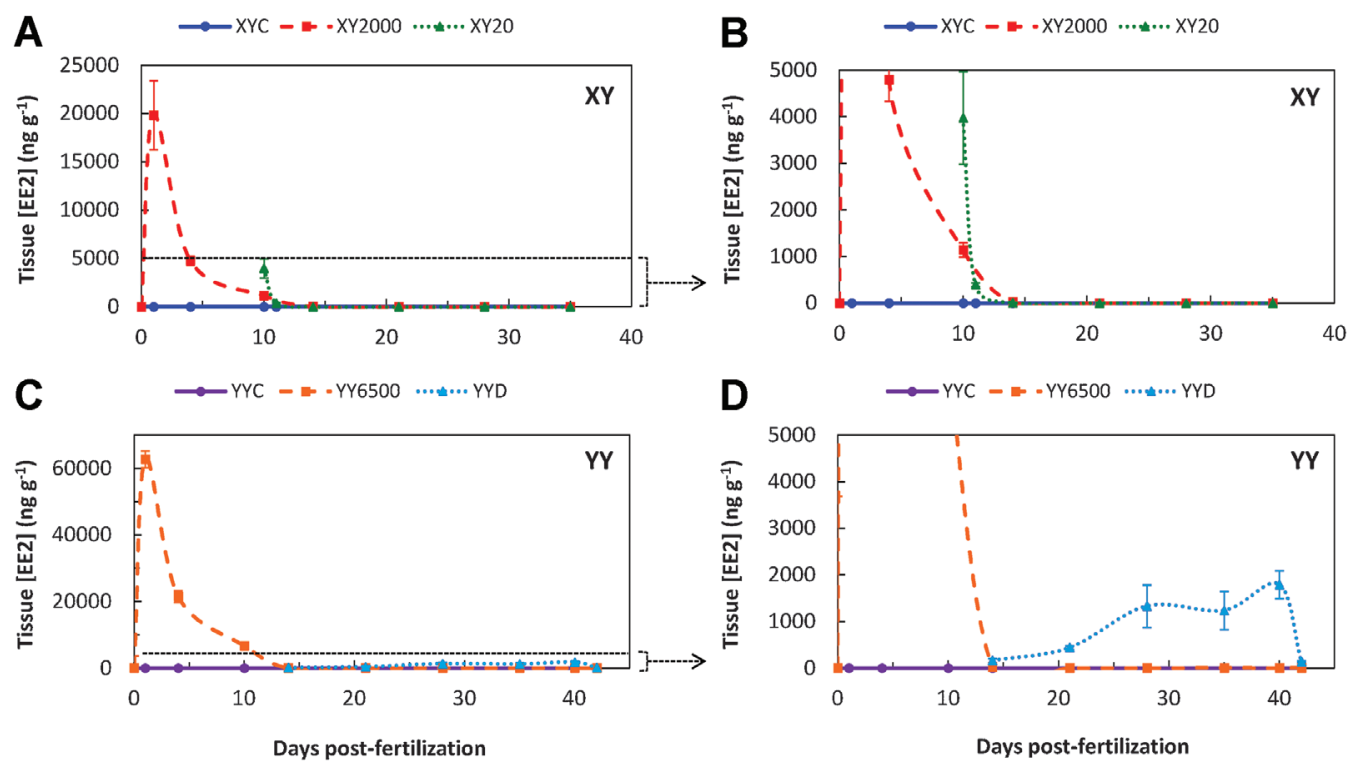

Figure 2. Mean $17 \alpha$-ethynylestradiol (EE2) tissue concentration in (A, B) $X Y(n=5$ progenies) and (C, D) $Y Y(n=4)$ progeny of Nile tilapia submitted to feminization treatments. A and $\mathbf{C}$ : complete profiles; $\mathbf{B}$ and $\mathbf{D}$ : data between 0 and $5000 \mathrm{ng} \mathrm{g}^{-1}$. $X Y C, X Y$ control group; $X Y 2000, X Y$ submitted to an EE2 immersion treatment $\left(2000 \mu \mathrm{g} \mathrm{L}^{-1}\right)$ for $4 \mathrm{hr}$ at $1 \mathrm{dpf} ; \mathrm{XY} 20, \mathrm{XY}$ immersed in EE2 at $20 \mu \mathrm{g} \mathrm{L}^{-1}$ for $4 \mathrm{hr}$ at $10 \mathrm{dpf}$. YYC, YY control group; YY6500, YY immersed in EE2 at $6500 \mu \mathrm{g} \mathrm{L}^{-1}$ for $4 \mathrm{hr}$ at $1 \mathrm{dpf}$; YYD, YY submitted to an EE2 dietary treatment of $500 \mathrm{mg} \mathrm{kg}^{-1}$ food from $10-40 \mathrm{dpf}$. 
A
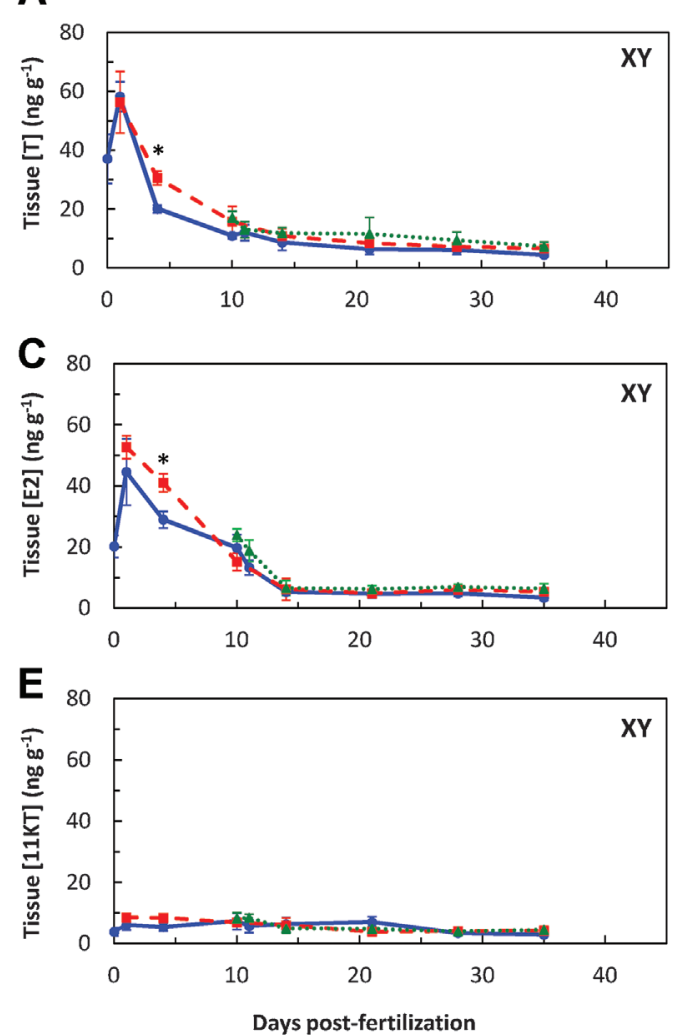

B $\rightarrow$ YYC - - $\cdot$ YY6500
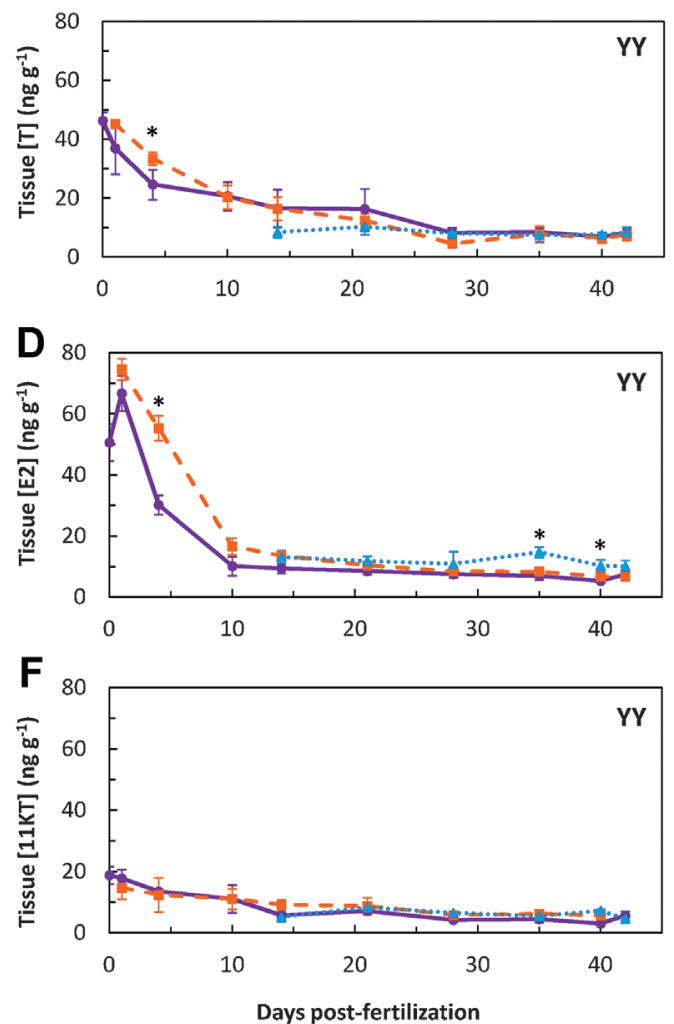

Figure 3. A, B: Mean testosterone (T), C, D: $17 \beta$-estradiol (E2), and E, F: 11-ketotestosterone tissue concentration in $X Y(n=5)$ and $Y Y(n=4)$ progenies of Nile tilapia submitted to feminization treatments. $X Y C, X Y$ control group; $X Y 2000, X Y$ submitted to an EE2 immersion treatment $\left(2000 \mu \mathrm{g} \mathrm{L}^{-1}\right)$ for $4 \mathrm{hr}$ at $1 \mathrm{dpf}$; XY20, XY immersed in EE2 at $20 \mu \mathrm{g} \mathrm{L}^{-1}$ for $4 \mathrm{hr}$ at $10 \mathrm{dpf}$. YYC, YY control group; YY6500, YY immersed in EE2 at $6500 \mathrm{\mu g} \mathrm{L}^{-1}$ for $4 \mathrm{hr}$ at $1 \mathrm{dpf}$; YYD, YY submitted to an EE2 dietary treatment of $500 \mathrm{mg} \mathrm{kg}^{-1}$ food from $10-40 \mathrm{dpf}$. ${ }^{*} P<0.05$.

and remained at a low level (between 5 and $15 \mathrm{ng} \mathrm{g}^{-1}$ ) until the end of the experimental period.

For both $X Y$ and $Y Y$ groups, individuals that received EE2 immersion treatment at $1 \mathrm{dpf}$ (XY2000 and YY6500) showed a significantly increased level of $\mathrm{T}$ and $\mathrm{E} 2$ at $4 \mathrm{dpf}$ compared to controls (Fig. 3A-D). No other significant differences were observed between controls and immersion-treated groups. E2 concentrations significantly increased in dietary EE2-treated $Y Y$ progeny at 35 and 40 dpf (Fig. 3D).

The profile of 11-ketotestosterone (11KT) was different than T or E2. In XY individuals (Fig. 3E), mean levels of 11KT were low and constant from $0-35 \mathrm{dpf}$ and did not exceed $7 \mathrm{ng} \mathrm{g}^{-1}$. YY eggs, however, contained a higher concentration of $11 \mathrm{KT}$ at $0 \mathrm{dpf}\left(19 \pm 3 \mathrm{ng} \mathrm{g}^{-1}\right)$ (Fig. 3F), but decreased thereafter until $10 \mathrm{dpf}$, settling at a similar level to the $X Y$ group. No significant difference was observed in $11 \mathrm{KT}$ levels between control and treated groups among any of the genotypes.

Overall, no correlation was observed between steroid levels in eggs at $0 \mathrm{dpf}$ and sex reversal rates.

\section{Expression Analysis of Sex-Differentiating Genes}

Early feminization treatments caused a strong and significant increase in cyp19a1b expression in the heads of tilapia embryos three days after the treatment (at $4 \mathrm{dpf}$ ) (Fig. 4A and B). In the XY2000 EE2-treated group, we observed a 2.4-fold change in the relative expression of this gene $(39.1 \pm 2.7 \%)$ compared to XYC controls $(16.1 \pm 1.2 \%)$ (Fig. 4A). Brain aromatase expression was even higher in immersion-treated $Y Y$ progeny (Fig. 4B), with a 3.5-fold increase in relative expression seen in the YY6500 $(64.7 \pm 5.6 \%)$ compared to YYC controls $(18.4 \pm 1.3 \%)$. No significant difference was observed between $X Y$ and $Y Y$ controls. On the other hand, $4 \mathrm{dpf}$ expression levels of amh and fox/2 were very low (Fig. $4 \mathrm{~A}$ and $\mathrm{B}$ ), and were not affected by the hormonal immersion treatments or by the genotype $(P>0.05)$.

None of the three analyzed genes showed a significant difference in expression levels between control and EE2-treated groups or between genotypes in the heads of $14 \mathrm{dpf}$ fry (Fig. 4C and D). Compared to $4 \mathrm{dpf}$, the relative expression of cyp19a1b was lower in all the groups (XYC, $10.2 \pm 1.6 \% ; \quad X Y 2000,11.9 \pm 3.7 \%$; YYC, $7 \pm 1.3 \%$; YY6500, $13.2 \pm 2.4 \%)$. Both amh and fox/2 expressions, however, were up-regulated at this age. From 4-14 dpf, amh expression increased from $1.0 \pm 0.5-16.2 \pm 2.3 \%$; from $0.5 \pm 0.2-12.9 \pm 3.1 \%$; from $1.1 \pm 0.3-30.4 \pm 15.6 \%$; and from $1.7 \pm 0.4-$ 

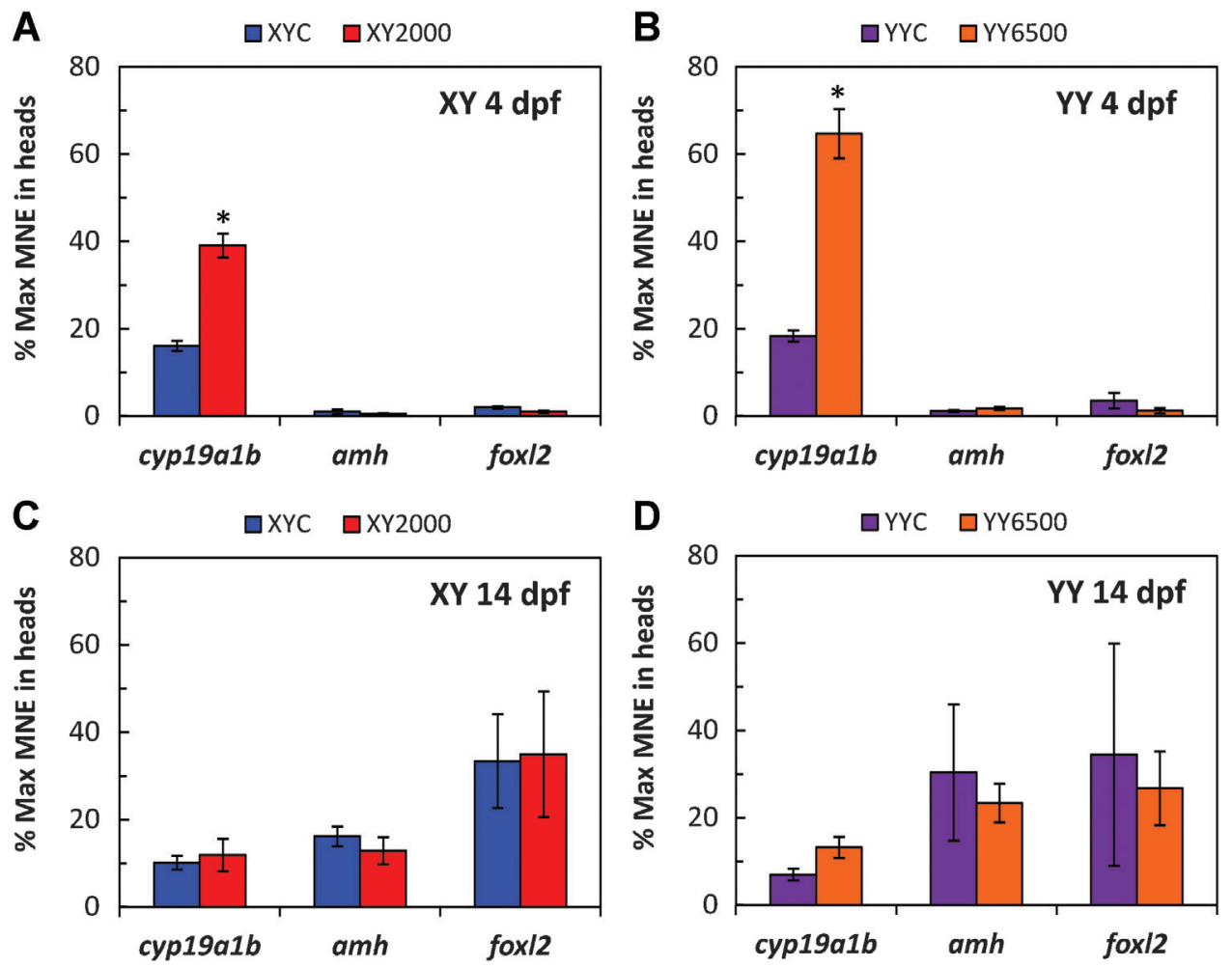

Figure 4. Mean relative expression of cyp19a1b, amh, and fox/2 at $4 \mathrm{dpf}(\mathbf{A}, \mathbf{B})$ and $14 \mathrm{dpf}(\mathbf{C}, \mathbf{D})$ in heads of $X Y(n=5)$ and $Y Y(n=4)$ progeny of Nile tilapia submitted to early-feminization treatment. $X Y C, X Y$ control group; $X Y 2000, X Y$ submitted to an EE2 immersion treatment (2000 $\mu \mathrm{g} \mathrm{L}^{-1}$ ) for $4 \mathrm{hr}$ at $1 \mathrm{dpf} ; \mathrm{XY} 20, \mathrm{XY}$ immersed in EE2 at $20 \mu \mathrm{g} \mathrm{L}{ }^{-1}$ for $4 \mathrm{hr}$ at $10 \mathrm{dpf}$. YYC, YY control group; YY6500, YY immersed in EE2 at $6500 \mu \mathrm{g} \mathrm{L}{ }^{-1}$ for $4 \mathrm{hr}$ at $1 \mathrm{dpf} ;$ YYD, YY submitted to an EE2 dietary treatment of $500 \mathrm{mg} \mathrm{kg}^{-1}$ food from $10-40 \mathrm{dpf} .{ }^{*} P<0.05$.

$23.4 \pm 4.4 \%$ in $X Y C ; X Y 2000$ YYC; and YY6500 groups, respectively. Fox/2 expression increased from $2.0 \pm 0.3-33.4 \pm 10.7 \%$; from $1.0 \pm 0.3-35.0 \pm 14.3 \%$; from $3.5 \pm 1.7-34.5 \pm 25.5 \%$; and from $1.2 \pm 0.6-$ $26.8 \pm 8.5 \%$ in $X Y C ; X Y 2000 Y Y C$; and $Y Y 6500$ groups, respectively.

No correlation was observed between changes in gene expression levels in control versus treated groups and sex reversal rates.

\section{DISCUSSION}

A 4 hr-immersion treatment in $2000 \mu \mathrm{g} \mathrm{EE} 2 \mathrm{~L}^{-1}$ at $1 \mathrm{dpf}$ induced up to $60 \%$ feminization in $\mathrm{XY}$ fish, confirming the existence of an early sensitive period for sex reversal during sex determination in the Nile tilapia. To our knowledge, this is the first time that early hormonal treatment was shown to induce sex reversal in tilapia. Similar feminizing treatments were performed on $\mathrm{O}$. mossambicus embryos by Rosenstein and Hulata (1992), but failed to induce a sexreversed phenotype. Our first work (Rougeot et al., 2008a) reported that immersion treatment in $100-500 \mu \mathrm{g}$ EE2 $\mathrm{L}^{-1}$ from $12 \mathrm{hpf}$ to $5 \mathrm{dpf}$ induced $55-68 \%$ sex reversal in $X Y$ individuals, but the duration of the treatment and the consequent persistence of exogenous estrogen in the developing fry (more than $5000 \mathrm{ng} \mathrm{g}^{-1}$ at $10 \mathrm{dpf}$; unpublished data) left some uncertainty about the actual period of exogenous estrogen activity. Here, we shortened the treatment period and used a higher EE2 concentration in order to focus on treating during the embryonic stage, thereby avoiding a delayed effect due to the accumulation of hormone after $10 \mathrm{dpf}$. As demonstrated by the low deviation in sex ratio induced by treating individuals at $10 \mathrm{dpf}$, residual hormone from the early treatment at $1 \mathrm{dpf}$ could not be responsible for the observed sex-reversed effect; the sex reversal phenotype is more likely caused by a mechanism operating before $10 \mathrm{dpf}$.

Complete sex reversal of $O$. niloticus $X Y$ fry, via an immersion treatment at the onset of gonad differentiation, was also achieved by Kobayashi et al. (2003) using similar or higher EE2 concentrations than we did (from 10-1000 $\mu \mathrm{g} \mathrm{L}^{-1}$ ) for a period of 3 days (from $8-10 \mathrm{dpf}$ ). An inverse relationship between dose and treatment duration has been reported for sex reversal (Piferrer, 2001), so it is likely that obtaining $60 \%$ sex reversal requires a higher estrogen intake at $10 \mathrm{dpf}$ than the residual concentration measured in individuals treated at $1 \mathrm{dpf}$. The increase in T and E2 concentrations and the up-regulation of cyp19a1b expression induced by the early treatment were observed at $4 \mathrm{dpf}$ but was not sustained by $14 \mathrm{dpf}$, suggesting that hormonal treatment acted only briefly on these parameters. The 
hormone-sensitive period of sex determination in embryos corresponds to the early thermo-sensitive period for masculinization that was determined by Rougeot et al. (2008b). As temperature likely does not act through accumulation or provide a substantial delayed effect, these two studies are consistent with the existence of an embryonic sensitive period during which sex can be reversed in Nile tilapia.

A brief hormone exposure avoided the drawback of reduced survival rates induced in thermal treatments (Rougeot et al., 2008b; Wessels et al., 2011) or by longer exposures (Rosenstein and Hulata, 1992; Rougeot et al., 2008a). Survival-rate values, however, have to be cautiously interpreted from this study; these rates were likely underestimated due to the timed sampling process, which introduced an important bias that more severely affected groups in which the number sampled represents a high proportion of the total number of fish (XY2000, XYC, YY6500, and YYC groups). Given the similar survival rates estimated in $X Y C$ and $X Y 2000$, on the one hand, and in YYC and YY6500, on the other hand, plus the low mortality observed during the experimental period, we can conclude that brief ( $4 \mathrm{hr}$ ) exposure of tilapia embryos to EE2 (up to $6500 \mu \mathrm{g} \mathrm{L}^{-1}$ ) does not affect their survival. Short immersions also did not adversely affect growth during the experimental period. This result contrasts with the impaired growth reported by Shved et al. (2008) following long-term exposure (from 10-100 dpf) of $X Y$ tilapia to environmentally relevant EE2 concentrations $\left(5-25 \mathrm{ng} \mathrm{L}^{-1}\right)$. Growth was also reduced in dietary EE2treated $X Y$ tilapia (at $125 \mathrm{mg} \mathrm{kg}^{-1}$ food) from $90 \mathrm{dpf}$, that is, 50 days after the end of the treatment (Shved et al., 2007); we similarly observed a $50 \%$ growth reduction in $Y Y$ fry fed with an EE2-supplemented diet (500 $\mathrm{mg} \mathrm{kg}^{-1}$ food) at the end of the treatment (42 dpf). This early decrease in growth might be attributed to a toxic effect of EE2 that arises with higher doses.

Early sex reversal in embryos by brief hormonal exposure was also observed in medaka (Kobayashi and Iwamatsu, 2005; Iwamatsu et al., 2005; 2006a). As medaka and Nile tilapia undergo similar morphogenesis during sex differentiation (Siegfried, 2010) and both present an early, sensitive sex-determining period long before gonadal differentiation, these two species are interesting models of gonochoristic teleosts for studying upstream sex-determining mechanisms. Unlike in medaka, however, no major sex determinant that is similar to the medaka dmy gene nor the involvement of primordial-germ-cell proliferation or their surrounding cells in the mechanism of early sex reversal (Kobayashi et al., 2004) has yet been defined in the Nile tilapia (Cnaani et al., 2008; Palaiokostas et al., 2013). On the other hand, Rougeot et al. (2008a) proposed and D'Cotta et al. (2001) provided evidence for a role of the brain in the sex-differentiation cascade. To explore this paradigm, we searched for sex-differentiating genes differentially expressed in the head of estrogen-immersed embryos.

Early estrogen treatments affected brain differentiation, as cyp19a1b was clearly up-regulated at $4 \mathrm{dpf}$ in those embryo heads exposed to EE2. Cyp19a1b is very sensitive to exogenous estrogens due to the presence of a con- served estrogen responsive element in its promoter (Diotel et al., 2010). Estrogens and high aromatase activity are recognized to play an important role in neurogenesis, although their role in brain sexual differentiation is still unclear (Le Page et al., 2010). Cyp19a1b is expressed in the brain early in development in different species, with a clear sexually dimorphic expression before the onset of gonad morphological differentiation reported in the rainbow trout (Vizziano-Cantonnet et al., 2011). In the pejerrey, cyp19a1b was not differentially expressed before the onset of sex differentiation at either female- or male-promoting temperatures; in adults, however, E2 treatments caused cyp19a1b up-regulation together with the estrogen receptors er $\alpha$ and er $\beta$ (Strobl-Mazzulla et al., 2008). No sex differences for cyp19a1b were found during development in medaka, although higher levels were observed in adult females (Okubo et al., 2011). In the Nile tilapia, the expression of the two genes coding for aromatase is initiated in embryos at 3-4 dpf (Kwon et al., 2001). During gonad differentiation, high expression level of the ovarian form of cyp19a1b (from $9 \mathrm{dph}$ ) is found in female gonads (D'Cotta et al., 2001; ljiri et al., 2008) while the brain form is expressed at the same level in XX and XY brains (Kwon et al., 2001), suggesting that in tilapia it plays a role in neurogenesis rather than in sexual differentiation.

Temperature-dependent sex reversal is accompanied by a decrease in brain aromatase activity during the sexdifferentiating period (D'Cotta et al., 2001), with higher brain aromatase activity in $X X$ females than in $X Y$ males under normal thermal conditions. This observation, together with our results, suggest that a role for the brain and particularly for brain aromatase in gonad sex differentiation cannot be ruled out, and that post-transcriptional control could be responsible for regulating sex-specific aromatase activity (Balthazart et al., 2011). In tilapia, sex-specific expression of cyp19a1b may be restricted to certain nuclei and not be readily observable. Comparison between $X Y$ and $Y Y$ genotypes showed that this increase in gene expression was dependent on EE2 dose, and was also associated with an increase in both $\mathrm{T}$ and $\mathrm{E} 2$ concentrations. While the increase in E2 synthesis was probably a result of the elevated cyp 19a1b levels induced by exogenous EE2, the increase in T suggests that estrogen treatment also up-regulated the expression or activity of other steroidogenic enzymes long before the gonad is formed. Despite these associations, the up-regulation of cyp19a1b in treated embryos cannot be entirely responsible for the sex-reversal effect seen in the present study as no sex reversal was observed in $Y Y$ progeny. If the brain is involved in the mechanism of early sex reversal, and consequently in early sex determination, this mechanism should be more complex and mostly likely require additional factors beyond aromatase.

To investigate one of the possible regulators of cyp19a1b expression, we measured the early expression of fox 2 in the brain of normal and sex-reversed $X Y$ and $Y Y$ tilapias. Transactivation studies have shown that the transcription factor fox/2, together with steroidogenic factor 1 (sf1), can activate the transcription of cyp19a1a by binding to its promoter (Wang et al., 2007). In tilapia gonads, fox/2 is co-expressed 
at the initiation of the ovarian differentiation, suggesting that it regulates in vivo cyp19a1a expression (Wang et al., 2007; ljiri et al., 2008) - although temporal co-expression was not evident in other tilapia strains and temperature-induced masculinization did not suppress expression of both genes simultaneously (Poonlaphdecha et al., 2013). Our present results also suggest that brain-expressed fox/2 does not regulate cyp19a1b expression, and does not participate in early sex reversal. We found very low or no expression of fox/2 in the embryonic head of XY controls and in EE2treated embryos, whereas cyp19a1b was markedly and differentially expressed between the two groups. As fox/2 expression is strongly induced by estrogens in the gonad (Baron et al., 2004; Wang et al., 2007), we postulate that this gene was totally repressed or not yet transcribed in the brain of tilapia embryos at the stage analyzed as fox/2 was expressed during gonad differentiation on $14 \mathrm{dpf}$ at a similar level in both $X Y$ and $Y Y$ fish and those treated with EE2. Consistent with our findings, fox $/ 2$ is not the only trigger regulating cyp19a1b in the brain in rainbow trout (VizzianoCantonnet et al., 2011), and a cooperative regulation of cyp19a $1 b$ by foxl2 and the nuclear receptor ftz-f1 has been demonstrated in Clarias gariepinus (Sridevi et al., 2012). More investigations are needed to understand the role of fox/2 in the brain of teleosts.

Amh was another candidate cerebral genetic factor that could be involved in early sexual reversal. In different species, amh and cyp19a1a have reciprocal expression profiles in the differentiating gonad (Wang and Orban 2007; Fernandino et al., 2008). In Nile tilapia, Poonlaphdecha et al. (2013) suggested that cyp19a1a inhibits amh expression in the gonads of genetic females. Amh is down-regulated by estrogens (Schulz et al., 2007; Fernandino et al., 2008 ) in the gonad, and sexually dimorphic expression levels are observed between genetic males and females in the tilapia brain at $14 \mathrm{dpf}$ (Poonlaphdecha et al., 2011). In our study, amh expression was totally repressed in embryos independent of EE2 exposure. As observed for fox/2, amh expression was initiated later in the brain and showed no difference between controls and EE2 sex-reversed fish. This suggests that the expression level of amh could be related to the sex genotype, and that a factor linked to the $Y$ chromosome may control its expression regardless of the sex phenotype.

The sensitivity of $X Y$ progeny to EE2 treatments varied widely among individuals, as demonstrated by the sexreversal rates ranging from $0-60 \%$. This variability could be related to the differential expression of sex-determining genes or to the endogenous steroid balance during ontogenesis and maternal steroid inheritance. In tilapia, estrogens are required for ovarian differentiation (Kobayashi et al., 2003; Nakamura, 2010) and are also involved in neurogenesis and brain sexualization, as suggested by the early expression of brain aromatase (Diotel et al., 2010; Le Page et al., 2010). Steroid metabolism is initiated early in embryogenesis as maternal hormones are metabolized during the first days of development (Hines et al., 1999). We therefore hypothesize that the steroid content of freshly fertilized eggs is maternally inherited and may influence the sex-determining mechanism. Yet, we did not find a correlation between steroid content (T, E2, and $11 \mathrm{KT}$ ) in freshly ovulated eggs and sex-reversal rates. Deviation from a 1:1 sex ratio in normal crosses (Lester et al., 1989) and heritable differences in temperature-related sex influences (Baroiller et al., 2009; Wessels and Hörstgen-Schwark, 2011) demonstrate that sex determination is multifactorial in tilapia; we suggest that such factors could further influence the responsiveness to early hormonal treatment.

If egg steroid content is not a determinant of sexual development, we postulate that a genetic determinant present on the sex chromosomes is responsible for the absence of early sex reversal in YY. For example, there could be a feminizing factor linked to the $X$ chromosome that is necessary to elicit a response to the estrogen treatment, or alternatively a masculinizing factor linked to the $Y$ chromosome wherein the presence of two copies represses or disables any feminizing effect of the exogenous hormone. The absence of sex reversal in $Y Y$ is nevertheless a striking and very interesting result as it suggests that an upstream genetic determinant linked to the sex chromosomes can influence sex determination in the first days of the embryogenesis, long before the earliest known evidence of a gonadal differential gene expression (9 dph) (ljiri et al., 2008).

In summary, we demonstrated for the first time that brief EE2 treatments during embryogenesis are effective in reversing $X Y$ tilapias towards a female phenotype, highlighting the existence of an early sensitive period for sex reversal during tilapia sex determination encompassing embryonic and larval development, prior to any sign of gonad differentiation. This early-embryo induced feminization was ineffective in $Y Y$ fish, suggesting that a $Y$-linked repressor may be modulator or alternatively that an activator on the $\mathrm{X}$ chromosome might be needed. Our embryonic feminizing procedure thus constitutes a new tool for identifying major, upstream sex determinants in the Nile tilapia.

\section{MATERIAL AND METHODS}

\section{Fish Stock Housing, Reproduction, and Juvenile Rearing}

Nile tilapia O. niloticus of the Lake Manzala strain were from the Research and Education Center in Aquaculture (CEFRA), University of Liège, Belgium. All-male $X Y$ progeny were obtained by artificial reproduction of $Y Y$ males with $X X$ females, and supermale $Y Y$ progenies from $Y Y$ males mated with $Y Y$ females, as described in Gennotte et al. (2012).

After artificial fertilization, eggs were weighed and counted. Each progeny was divided into three batches (for the XY group: controls, a 4-hr-treated group at $1 \mathrm{dpf}$, and a $10 \mathrm{dpf}$-treated group; for the YY group: controls, a 4hr-treated group at $1 \mathrm{dpf}$, and a 30-day diet-treated group) and incubated in $1.5 \mathrm{~L}$ Zug bottles at $27^{\circ} \mathrm{C}$. Fertilization rates were evaluated on 100 eggs after the first mitotic cleavage (2 hpf) (Morrison et al., 2001). Hatching rates were assessed by counting all fish from each batch at $4 \mathrm{dpf}$. 
Larvae were transferred at $8 \mathrm{dpf}$ into $50-\mathrm{L}$ aquaria (mean stocking density \pm standard deviation of $5.4 \pm 1.7$ fish $\mathrm{L}^{-1}$ ) and feeding started at $10 \mathrm{dpf}$. In order to determine the food ratio and follow the growth and survival of each batch, the number of individuals and total biomass were recorded every week from $8 \mathrm{dpf}$ to $35 \mathrm{dpf}(\mathrm{XY})$ or 42 (YY) dpf. Homogenization of fish growth between treated and control groups, and among progeny, was essential to standardize the developmental speed and the post-treatment kinetics of EE2 clearance. Fish were fed close to satiation, and food ratios were adjusted to assure the same growth in all batches. Food distribution was performed six times a day with a commercial tilapia diet (47\% proteins, $8 \%$ lipids) (Coppens, The Netherlands). Experiments were carried out according to the guidelines of the University of Liège ethical committee and the European animal welfare recommendations.

\section{$17 \alpha$-Ethynylestradiol Solutions}

$17 \alpha$-ethynylestradiol (Sigma-Aldrich, Saint-Louis, MO, US) was dissolved in $100 \%$ ethanol, and then stored at $4{ }^{\circ} \mathrm{C}$. Stock solutions were prepared at different concentrations: 20,2000 , and $6500 \mathrm{mg} \mathrm{L}^{-1}$. For each experiment, $1 \mathrm{ml}$ of stock solution was added to $1 \mathrm{~L}$ of water. Control groups were incubated in a 1:1000-diluted ethanol solution. For the YY feminization group treated with EE2-supplemented feed, $500 \mathrm{mg}$ of EE2 was dissolved in $600 \mathrm{ml}$ of $95 \%$ ethanol, and mixed with $1 \mathrm{~kg}$ of food pellets. It was then allowed to dry and stored at $4{ }^{\circ} \mathrm{C}$.

\section{Early Feminization of $\mathrm{XY}$ Individuals}

To test the sex-inversion efficiency of hormonal treatment on developing embryos, feminization treatments were applied to one of the five $X Y$ progeny batches. The treatment consisted of a single $4 \mathrm{hr}$ immersion in a $2000 \mu \mathrm{g} \mathrm{EE} 2 \mathrm{~L}^{-1}$ solution (XY2000 group) at $1 \mathrm{dpf}$, and was conducted by transferring the eggs from the Zug bottle into a $1-L$ glass beaker filled with hatchery water and maintained in a thermostatic bath at $27^{\circ} \mathrm{C}$. One milliliter of stock solution (ethanol for control groups) was then added to the water. During incubation, the waterwas oxygenated by an air diffuser. After $4 \mathrm{hr}$ of immersion, the eggs were netted, the solution gently removed by soaking on paper, and the eggs were rinsed in six different baths to remove hormone residues. The first three baths contained 1:1000 ethanol and the next three had only hatchery water. The batches corresponding to control groups $(X Y C)$ were handled in the same way. After rinsing, eggs were returned to the hatchery.

In order to verify that the $1 \mathrm{dpf}$ feminization treatment targeted the early developmental stages before 10 days rather than by tissue accumulation of the hormone followed by a delayed effect after $10 \mathrm{dpf}$, we treated the third batch of each progeny at $10 \mathrm{dpf}$ with a 4 -hr immersion in a $20 \mu \mathrm{g} \mathrm{EE} 2$ $\mathrm{L}^{-1}$ solution (XY20 group). This lower dose was used to reach an EE2 tissue concentration similar to the residual concentration measured in the XY2000 group at $10 \mathrm{dpf}$. The immersion procedure was essentially the same as the egg treatment.
For steroid analysis, individuals were sampled in $\mathrm{XYC}$, $X Y 2000$, and $X Y 20$ groups at 0 (unfertilized eggs, $n=67$ $-100), 1(n=80-100), 4(n=70-100), 10(n=40-60), 11$ $(n=20-40), 14 \quad(n=15-30), 21 \quad(n=6-10), 28 \quad(n=6$ $-10)$, and $35(n=6-10)$ dpf. Samples were weighed and stored at $-80^{\circ} \mathrm{C}$ until needed for steroid extraction.

Gene expression analysis was performed on individuals sampled at $4(n=50)$ and $14(n=20-50)$ dpf in control and XY2000 groups. Samples were preserved in RNA Later (Ambion, Austin, TX, US) at $-20^{\circ} \mathrm{C}$ following the manufacturer's instructions, before RNA extraction.

\section{Early Feminization of YY Individuals}

Four YY progeny batches were produced and divided into three. The treated batches were immersed for $4 \mathrm{hr}$ in a $6500 \mu \mathrm{g} \mathrm{EE} 2 \mathrm{~L}^{-1}$ solution at $1 \mathrm{dpf}$ (YY6500), following the same protocol as described above for the $\mathrm{XY}$-treated eggs. Preliminary results (unpublished) showed that treatment with a $2000 \mu \mathrm{gEE} 2 \mathrm{~L}^{-1}$ solution had no effect on $Y Y$ sex reversal, so we increased the EE2 concentration for the YY treatment in proportion to the EE2 concentrations used in the dietaryhormone treatment $\left(150 \mathrm{mg} \mathrm{kg}^{-1}\right.$ for $X Y$ and $500 \mathrm{mg} \mathrm{kg}^{-1}$ for YY) (unpublished data). Control batches (YYC) were immersed in a solution containing only ethanol $(1: 1000)$. The third group (YYD) was fed dietary hormone, and this batch served as a positive control for sex reversal. The fry from the YYD batch were fed a EE2-supplemented diet $\left(500 \mathrm{mg} \mathrm{kg}^{-1}\right.$ food) ad libitum from 10-40 dpf to verify the susceptibility of each progeny to the feminization treatmentapplied during the known sensitive period of sex differentiation.

Samplings for steroid analysis were carried out in YYC, YY6500, and YYD at 0 (unfertilized eggs, $n=100$ ), $1 \quad(n=80-100), 4 \quad(n=65-150), \quad 10 \quad(n=30-100)$, $14(n=15-60), 21(n=6-15), 28(n=6-10), 35(n=6$ $-10), 40(n=6-10)$, and $42(n=6-10) d p f$. Samples were weighed and stored at $-80^{\circ} \mathrm{C}$ until needed for steroid extraction.

Gene-expression analysis was performed on individuals sampled at $4(n=40-50)$ and $14(n=20-50)$ dpf in control and YY6500 groups. Samples were preserved in RNA Later (Ambion) at $-20^{\circ} \mathrm{C}$, following the manufacturer's instructions, before RNA extraction.

\section{Sex-Ratio Analysis}

Phenotypic sex was determined by the acetocarmine squash method (Guerrero and Shelton, 1974) at $90 \mathrm{dpf}$. Fish were euthanized by an overdose $\left(500 \mathrm{mg} \mathrm{L}^{-1}\right)$ of benzocaine (Sigma-Aldrich), and a slice of the gonads from 53-125 fish per batch was microscopically examined after acetocarmine coloration.

\section{Steroid Extraction}

Steroids were extracted from homogenized samples $(0.25-1.15 \mathrm{~g}$ weight) following a procedure described in D'Cotta et al. (2001). After three extractions with dichloromethane, extracts were suspended in $300 \mu$ l of $100 \%$ ethanol and stored at $-20^{\circ} \mathrm{C}$ until needed for assessment. 
TABLE 2. Primers Used for the Quantitative Real-Time PCR

\begin{tabular}{|c|c|c|c|}
\hline Gene & $\begin{array}{c}\text { GenBank } \\
\text { accession number }\end{array}$ & Forward primer & Reverse primer \\
\hline $\begin{array}{l}\text { cyp19a1b } \\
\text { amh } \\
\text { fox/2 } \\
\text { ef1 } \alpha\end{array}$ & $\begin{array}{l}\text { AF295761 } \\
\text { EF512167 } \\
\text { AY554172 } \\
\text { AB075952 }\end{array}$ & $\begin{array}{c}\text { F957: 5'-GATTCATGAAGCCGAGAAGC } \\
\text { F1577: 5'-AAGCAGCGCAAACATTAACA } \\
\text { F310: 5'-AAGAGGAGCCGGTTCAGGACAA } \\
\text { F832: 5'-TGTTGAGACTGGTATCCTGAAGCC }\end{array}$ & $\begin{array}{c}\text { R1184: 5'-TTCAAGATGGTGTTCATCATCTCCT } \\
\text { R1741: 5'-GTTCCAGTCCACAACCTCCA } \\
\text { R396: 5'-GCTCTCCCGGATAGCCATGG } \\
\text { R1072: 5'-GATGATGACCTGAGCGTTGAAGC }\end{array}$ \\
\hline
\end{tabular}

\section{EE2 Enzyme Immunoassay}

EE2 was assayed by enzyme-linked immunosorbent assay following the manufacturer's instructions (Europroxima, The Netherlands). Twenty microliters of extract were dissolved in $180 \mu \mathrm{l}$ of dilution buffer provided with the kit. Each sample from treated groups was further diluted to reach a concentration in the detection range $(0.02-2 \mathrm{ng}$ $\mathrm{g}^{-1}$ ) of the kit. All samples were assayed in duplicate.

\section{Testosterone, 17 $\beta$-Estradiol, and 11- Ketotestosterone Radioimmunoassays}

Testosterone (T), 17 $\beta$-estradiol (E2), and 11-ketotestosterone $(11 \mathrm{KT})$ concentrations were assayed in developing eggs, larvae, and juveniles by radioimmunoassay, as described in Douxfils et al. (2007). Radioactive hormones were purchased from Amersham Pharmacia (Buckingamshire, England). $T$ and E2 antibodies were obtained from the Laboratoire d'Hormonologie de Marloie (CER, Belgium), and the anti-11KT was a gift from A. Fostier (INRA, Rennes, France). Detection limits ranged from $50-80 \mathrm{pg} \mathrm{ml}^{-1}$.

\section{Total RNA Extraction and Reverse Transcription}

Heads were dissected from their trunks under a stereomicroscope, and placed in RNA Later. Each batch sampled was divided into two or three replicates, and each replicate contained from $6-17$ heads. Total RNA was extracted from pooled heads using TRIzol reagent (Invitrogen, Carlsbad, CA, US), following the manufacturer's protocol, after which total RNA was resuspended in $30-150 \mu \mathrm{l}$ of RNase-free water and quantified with a NanoDrop (Thermo Scientific, Wilmington, DE, US). Extracts were treated to remove genomic DNA with TURBO DNase (Ambion), and single-strand cDNA was produced using SuperScript II reverse transcriptase (Invitrogen), as described in Poonlaphdecha et al. (2011). Reverse transcription was performed with 5 and $4 \mu \mathrm{g}$ of total RNA for samples from 4 and $14 \mathrm{dpf}$, respectively. The cDNA was diluted in water to $25 \mathrm{ng} \mu l^{-1}$ and stored at $-20^{\circ} \mathrm{C}$ for quantitative real-time PCR.

\section{Quantitative Real-Time PCR Analysis}

Expression levels of cyp19a1b, amh, and fox/2 were studied in embryo (4 dpf) and fry heads (14 dpf). Quantitative PCR was performed on a MX3000P (cyp19a1b and amh) or MX3005P (fox/2) real-time PCR system (Stratagene, La Jolla, CA, US). Due to its expression stability during estrogen exposure (data not published), ef $1 \alpha$ was used as a reference to standardize gene expression levels. The primers used are listed in Table 2. All biological replicates were analyzed in duplicate from $10 \mu$ l reactions using Brilliant II SYBR ${ }^{\circledR}$ Green QPCR Master Mix (Agilent Technologies, Santa Clara, CA, US). Reactions were run with $50 \mathrm{ng}$ cDNA and a concentration of $300 \mathrm{nM}$ for each primer. PCR cycling parameters, control of reaction specificity, and calculation method for gene expression levels (expressed as mean normalized expression) are described in Poonlaphdecha et al. (2011, 2013).

\section{Data Analysis}

Data are reported as mean \pm standard error of the mean. Mean values of growth, steroid concentrations, and relative gene expressions were compared between groups (treated versus control). Normality was analyzed with the Shapiro-Wilk test, and homoscedasticity with the Levene test. If data complied with these two conditions, differences between means were searched by ANOVA, and multiple comparisons were performed with the Fisher's LSD test. Otherwise, nonparametric Kruskal-Wallis test and Mann-Whitney test were used. The chi-squared test was used to analyze survival and sex reversal rates. Spearman rank correlation coefficients were used to identify correlations between sex reversal rates, steroid concentrations in unfertilized eggs, and changes in gene expression levels. Differences were considered as significant at $P<0.05$. Statistical analysis was performed using Statistica v.10 (StatSoft, France).

\section{ACKNOWLEDGMENTS}

We are grateful to Christian Prignon and Denis Gustin for their help in fish housing and sex-ratio analysis, and to Thomas Tomson for his help with the radioimmunoassays. Thanks to Robert Mandiki (University of Namur) for his supervision of radioimmunoassay analysis, to Alexis Fostier for his $11 \mathrm{KT}$ antibody (INRA, Rennes, France), Elodie Pepey (Cirad), and Titus Ndiwa for their assistance in quantitative real-time PCR. V. Gennotte was a Ph.D. grant holder from FRIA-FNRS (Fonds pour la Formation et la Recherche dans l'Industrie et dans l'Agriculture). This study was supported by ULg (crédit classique 2010).

\section{REFERENCES}

Afonso LOB, Wassermann GJ, De Oliveira RT. 2001. Sex reversal in Nile tilapia (Oreochromis niloticus) using a nonsteroidal aromatase inhibitor. J Exp Zool 290:177-181. 
Balthazart J, Charlier TD, Cornil CA, Dickens MJ, Harada N, Konkle ATM, Voigt C, Ball GF. 2011. Sex differences in brain aromatase activity: Genomic and non-genomic controls. Front Endocrinol 34:1-13.

Baroiller JF, Chourrout D, Fostier A, Jalabert B. 1995. Temperature and sex chromosomes govern sex ratios of the mouthbrooding cichlid fish Oreochromis niloticus. J Exp Zool 273:216-223.

Baroiller JF, D'Cotta H, Bezault E, Wessels S, Hoerstgen-Schwark G. 2009. Tilapia sex determination: where temperature and genetics meet. Comp Biochem Phys A Physiol 153:30-38.

Baroiller JF, Guiguen Y, Fostier A. 1999. Endocrine and environmental aspects of sex differentiation in fish. Cell Mol Life Sci 55:910-931.

Baron D, Cocquet J, Xia X, Fellous M, Guiguen Y, Veitia RA. 2004. An evolutionary and functional analysis of Foxl2 in rainbow trout gonad differentiation. J Mol Endocrinol 33:705-715.

Blázquez M, Somoza GM. 2010. Fish with thermolabile sex determination (TSD) as models to study brain sex differentiation. Gen Comp Endocrinol 166:470-477.

Cnaani A, Lee BY, Zilberman N, Ozouf-Costaz C, Hulata G, Ron M, D'Hont A, Baroiller JF, D'Cotta H, Penman DJ, Tomasino E, Coutanceau JP, Pepey E, Shirak A, Kocher TD. 2008. Genetics of sex determination in tilapiine species. Sex Dev 2:43-54

D'Cotta H, Fostier A, Guiguen Y, Govoroun M, Baroiller JF. 2001. Aromatase plays a key role during normal and temperatureinduced sex differentiation of tilapia Oreochromis niloticus. Mol Reprod Dev 59:265-276.

Devlin RH, Nagahama Y. 2002. Sex determination and sex differentiation in fish: An overview of genetic, physiological, and environmental influences. Aquaculture 208:191-364.

Diotel N, Page YL, Mouriec K, Tong SK, Pellegrini E, Vaillant C, Anglade I, Brion F, Pakdel F, Chung BC, Kah O. 2010. Aromatase in the brain of teleost fish: Expression, regulation and putative functions. Front Neuroendocrinol 31:172-192.

Douxfils J, Mandiki R, Silvestre F, Bertrand A, Leroy D, Thomé J-P, Kestemont P. 2007. Do sewage treatment plant discharges substantially impair fish reproduction in polluted rivers. Sci Total Environ 372:497-514.

Fernandino JI, Hattori RS, Kimura H, Strüssmann CA, Somoza GM. 2008. Expression profile and estrogenic regulation of anti-Müllerian hormone during gonadal development in pejerrey Odontesthes bonariensis, a teleost fish with strong temperature-dependent sex determination. Dev Dyn 237: 3192-3199.

Gennotte V, Sawadogo P, Milla S, Kestemont P, Mélard C, Rougeot C. 2012. Cortisol is responsible for positive and negative effects in the ovarian maturation induced by the exposure to acute stressors in Nile tilapia, Oreochromis niloticus. Fish Physiol Biochem 38:1619-1626.

Guerrero RD, Shelton WL. 1974. An aceto-carmine squash method for sexing juvenile fishes. Prog Fish Cult 36:56-56.
Guiguen Y, Fostier A, Piferrer F, Chang CF. 2010. Ovarian aromatase and estrogens: A pivotal role for gonadal sex differentiation and sex change in fish. Gen Comp Endocrinol 165:352-366

Hattori RS, Murai Y, Oura M, Masuda S, Majhi SK, Sakamoto T, Fernandino JI, Somoza GM, Yokota M, Strussmann CA. 2012. A Y-linked anti-Müllerian hormone duplication takes over a critical role in sex determination. P Natl Acad Sci USA 109:2955-2959.

Hines GA, Boots LR, Wibbels T, Watts SA. 1999. Steroid levels and steroid metabolism in relation to early gonadal development in the tilapia Oreochromis niloticus (teleostei: Cyprinoidei). Gen Comp Endocrinol 114:235-248.

Ijiri S, Kaneko H, Kobayashi T, Wang D-S, Sakai F, Paul-Prasanth B, Nakamura M, Nagahama Y. 2008. Sexual dimorphic expression of genes in gonads during early differentiation of a teleost fish, the Nile tilapia Oreochromis niloticus. Biol Reprod 78:333-341.

Iwamatsu T, Kobayashi H, Hamaguchi S, Sagegami R, Shuo T. 2005. Estradiol-17 $\beta$ content in developing eggs and induced sex reversal of the medaka (Oryzias latipes). J Exp Zool 303:161-167.

Iwamatsu T, Kobayashi H, Sagegami R, Shuo T. 2006a. Testosterone content of developing eggs and sex reversal in the medaka (Oryzias latipes). Gen Comp Endocrinol 145:67-74.

Jalabert B, Moreau J, Planquette P, Billard R. 1974. Déterminisme du sexe chez Tilapia macrochir et Tilapia nilotica: Action de la méthyltestostérone dans l'alimentation des alevins sur la différentiation sexuelle; proportion des sexes dans la descendance des mâles "inversés". Ann Biol anim Bioch Biophys 14:729-739.

Kamiya T, Kai W, Tasumi S, Oka A, Matsunaga T, Mizuno N, Fujita M, Suetake H, Suzuki S, Hosoya S, Tohari S, Brenner S, Miyadai T, Venkatesh B, Suzuki Y, Kikuchi K. 2012. A transspecies missense SNP in Amhr2 is associated with sex determination in the tiger pufferfish, Takifugu rubripes (fugu). PLoS Genet 8:e1002798.

Kobayashi H, Iwamatsu T. 2005. Sex reversal in the medaka Oryzias latipes by brief exposure of early embryos to estradiol-17ß. Zool Sci 22:1163-1167.

Kobayashi T, Kajiura-Kobayashi H, Guan G, Nagahama Y. 2008. Sexual dimorphic expression of DMRT1 and Sox9a during gonadal differentiation and hormone-induced sex reversal in the teleost fish Nile tilapia (Oreochromis niloticus). Dev Dyn 237:297-306.

Kobayashi T, Kajiura-Kobayashi H, Nagahama Y. 2003. Induction of $X Y$ sex reversal by estrogen involves altered gene expression in a teleost, tilapia. Cytogenet Genome Res 101:289-294.

Kobayashi T, Matsuda M, Kajiura-Kobayashi H, Suzuki A, Saito N, Nakamoto M, Shibata N, Nagahama Y. 2004. Two DM domain genes, DMY and DMRT1, involved in testicular differentiation and development in the medaka, Oryzias latipes. Dev Dyn 231:518-526. 
Kwon JY, McAndrew BJ, Penman DJ. 2001. Cloning of brain aromatase gene and expression of brain and ovarian aromatase genes during sexual differentiation in genetic male and female Nile tilapia Oreochromis niloticus. Mol Reprod Dev 59:359-370.

Le Page Y, Diotel N, Vaillant C, Pellegrini E, Anglade I, Mérot Y, Kah O. 2010. Aromatase, brain sexualization and plasticity: The fish paradigm. Eur J Neurosci 32:2105-2115.

Lester LJ, Lawson KS, Abella TA, Palada MS. 1989. Estimated heritability of sex ratio and sexual dimorphism in tilapia. Aquac Res 20:369-380.

Loffler KA, Zarkower D, Koopman P. 2003. Etiology of ovarian failure in blepharophimosis ptosis epicanthus inversus syndrome: FOXL2 is a conserved, early-acting gene in vertebrate ovarian development. Endocrinology 144:3237-3243.

Matsuda M, Nagahama Y, Shinomiya A, Sato T, Matsuda C, Kobayashi T, Morrey CE, Shibata N, Asakawa S, Shimizu N, Hori H, Hamaguchi S, Sakaizumi M. 2002. DMY is a Y-specific DM-domain gene required for male development in the medaka fish. Nature 417:559-563.

Morrison CM, Miyake T, Wright JRJ. 2001. Histological study of the development of the embryo and early larva of Oreochromis niloticus (pisces: Cichlidae). J Morphol 247:172-195.

Myosho T, Otake H, Masuyama H, Matsuda M, Kuroki Y, Fujiyama A, Naruse K, Hamaguchi S, Sakaizumi M. 2012. Tracing the emergence of a novel sex-determining gene in medaka, Oryzias luzonensis. Genetics 191:163-170.

Nakamoto M, Matsuda M, Wang DS, Nagahama Y, Shibata N. 2006. Molecular cloning and analysis of gonadal expression of Foxl2 in the medaka. Oryzias latipes. 344:353-361.

Nakamura M. 2010. The mechanism of sex determination in vertebrates-Are sex steroids the key-factor. J Exp Zool 313:381-398.

Okubo K, Takeuchi A, Chaube R, Paul-Prasanth B, Kanda S, OkaY, Nagahama Y. 2011. Sex differences in aromatase gene expression in the Medaka brain. J Neuroendocrinol 23:412-423.

Palaiokostas C, Bekaert M, Khan MG, Taggart JB, Gharbi K, McAndrew BJ, Penman DJ. 2013. Mapping and validation of the major sex-determining region in Nile tilapia (Oreochromis niloticus L.) using RAD sequencing. PLoS ONE 8: e68389.

Piferrer F. 2001. Endocrine sex control strategies for the feminization of teleost fish. Aquaculture 197:229-281.

Piferrer F, Donaldson E. 1994. Uptake and clearance of exogenous estradiol-17 $\beta$ and testosterone during the early development of coho salmon (Oncorhynchus kisutch), including eggs, alevins and fry. Fish Physiol Biochem 13:219-232.

Piferrer F, Zanuy S, Carrillo M, Solar II, Devlin RH, Donaldson EM. 1994. Brief treatment with an aromatase inhibitor during sex differentiation causes chromosomally female salmon to develop as normal, functional males. J Exp Zool 270:255-262.

Poonlaphdecha S, Pepey E, Canonne M, de Verdal H, Baroiller JF, D'Cotta H. 2013. Temperature induced-masculinisation in the
Nile tilapia causes rapid up-regulation of both dmrt1 and amh expressions. Gen Comp Endocrinol 193:234-242.

Poonlaphdecha S, Pepey E, Huang SH, Canonne M, Soler L, Mortaji S, Morand S, Pfennig F, Mélard C, Baroiller JF, D'Cotta H. 2011. Elevated amh gene expression in the brain of male tilapia (Oreochromis niloticus) during testis differentiation. Sex Dev 5:33-47.

Rosenstein S, Hulata G. 1992. Sex reversal in the genus Oreochromis: 1. Immersion of eggs and embryos in oestrogen solutions is ineffective. Aquacult Fish Manage 23:669-678.

Rougeot C, Kanfitine SY, Prignon C, Gennotte V, Mélard C. 2008a. Early sex reversal during the embryonic development in the Nile tilapia. Cybium 32:104-105.

Rougeot C, Prignon C, Ngouana Kengne, Mélard CV. 2008b. Effect of high temperature during embryogenesis on the sex differentiation process in the Nile tilapia, Oreochromis niloticus. Aquaculture 276:205-208.

Schulz RW, Bogerd J, Male R, Ball J, Fenske M, Olsen LC, Tyler CR. 2007. Estrogen-induced alterations in amh and dmrt1 expression signal for disruption in male sexual development in the zebrafish. Environ Sci Technol 41:6305-6310.

Shved N, Berishvili G, D'Cotta H, Baroiller JF, Segner H, Eppler E, Reinecke M. 2007. Ethinylestradiol differentially interferes with IGF-I in liver and extrahepatic sites during development of male and female bony fish. J Endocrinol 195:513-523.

Shved N, Berishvili G, Baroiller JF, Segner H, Reinecke M. 2008. Environmentally relevant concentrations of $17 \alpha$-ethinylestradiol (EE2) interfere with the growth hormone $(\mathrm{GH}) /$ insulin-like growth factor (IGF)-I system in developing bony fish. Toxicol Sci 106:93-102.

Siegfried KR. 2010. In search of determinants: Gene expression during gonadal sex differentiation. J Fish Biol 76:1879-1902.

Sinclair AH, Berta P, Palmer MS, Hawkins JR, Griffiths BL, Smith MJ, Foster JW, Frischauf A-M, Lovell-Badge R, Goodfellow PN. 1990. A gene from the human sex-determining region encodes a protein with homology to a conserved DNA-binding motif. Nature 346:240-244.

Sridevi P, Chaitanya RK, Dutta-Gupta A, Senthilkumaran B. 2012. FTZ-F1 and FOXL2 up-regulate catfish brain aromatase gene transcription by specific binding to the promoter motifs. Biochim Biophys Acta 1819:57-66.

Strobl-Mazzulla PH, Lethimonier C, Gueguen MM, Karube M, Fernandino JI, Yoshizaki G, Patino R, Strussmann CA, Kah O, Somoza GM. 2008. Brain aromatase (Cyp19A2) and estrogen receptors, in larvae and adult pejerrey fish Odontesthes bonariensis: Neuroanatomical and functional relations. Gen Comp Endocrinol 158:191-201.

Tchoudakova A, Callard GV. 1998. Identification of multiple CYP19 genes encoding different cytochrome P450 aromatase isozymes in brain and ovary. Endocrinology 139:2179-2189.

Tsai CL, Chang SL, Wang LH, Chao TY. 2003. Temperature influences the ontogenetic expression of aromatase and 
oestrogen receptor mRNA in the developing tilapia (Oreochromis mossambicus) brain. J Neuroendocrinol 15:97-102.

Uchida D, Yamashita M, Kitano T, Iguchi T. 2004. An aromatase inhibitor or high water temperature induce oocyte apoptosis and depletion of P450 aromatase activity in the gonads of genetic female zebrafish during sex-reversal. Comp Biochem Phys A Physiol 137:11-20.

Vizziano-Cantonnet D, Anglade I, Pellegrini E, Gueguen MM, Fostier A, Guiguen Y, Kah O. 2011. Sexual dimorphism in the brain aromatase expression and activity, and in the central expression of other steroidogenic enzymes during the period of sex differentiation in monosex rainbow trout populations. Gen Comp Endocrinol 170:346-355.

von Schalburg KR, Yasuike M, Davidson WS, Koop BF. 2010. Regulation, expression and characterization of aromatase (cyp19b1) transcripts in ovary and testis of rainbow trout (Oncorhynchus mykiss). Comp Biochem Phys B Biochem Mol Biol 155:118-125.

Wang DS, Kobayashi T, Zhou LY, Paul-Prasanth B, ljiri S, Sakai F, Okubo K, Morohashi KI, Nagahama Y. 2007. Foxl2 up-regulates aromatase gene transcription in a female-specific manner by binding to the promoter as well as interacting with ad4 binding protein/steroidogenic factor 1. Mol Endocrinol 21: 712-725.

Wang XG, Orban L. 2007. Anti-Müllerian hormone and $11 \beta$-hydroxylase show reciprocal expression to that of aromatase in the transforming gonad of zebrafish males. Dev Dyn 236:1329-1338.

Wessels S, Hörstgen-Schwark G. 2011. Temperature dependent sex ratios in selected lines and crosses with a YY-male in Nile tilapia (Oreochromis niloticus). Aquaculture 318:79-84.

Wessels S, Samavati S, Hörstgen-Schwark G. 2011. Effect of early temperature treatments on sex differentiation in Nile tilapia, Oreochromis niloticus lines selected for high and low thermo-sensitivity. Aquaculture 316:139-142.

Yano A, Guyomard R, Nicol B, Jouanno E, Quillet E, Klopp C, Cabau C, Bouchez O, Fostier A, Guiguen Y. 2012. An immunerelated gene evolved into the master sex-determining gene in rainbow trout, Oncorhynchus mykiss. Curr Biol 22: 1423-1428. 